\title{
Origin of tropospheric ozone at remote high northern latitudes in summer
}

\section{Citation}

Mauzerall, D. L., D. J. Jacob, S.-M. Fan, J. D. Bradshaw, G. L. Gregory, G. W. Sachse, and D. R. Blake. 1996. "Origin of Tropospheric Ozone at Remote High Northern Latitudes in Summer." Journal of Geophysical Research 101 (D2): 4175-4188. doi:10.1029/95jd03224.

\section{Published Version}

doi:10.1029/95JD03224

\section{Permanent link}

http://nrs.harvard.edu/urn-3:HUL.InstRepos:14121761

\section{Terms of Use}

This article was downloaded from Harvard University's DASH repository, and is made available under the terms and conditions applicable to Other Posted Material, as set forth at http:// nrs.harvard.edu/urn-3:HUL.InstRepos:dash.current.terms-of-use\#LAA

\section{Share Your Story}

The Harvard community has made this article openly available.

Please share how this access benefits you. Submit a story.

\section{Accessibility}




\title{
Origin of tropospheric ozone at remote high northern latitudes in summer
}

\author{
D.L. Mauzerall', D.J. Jacob', S.-M. Fan ${ }^{1,2}$, J.D. Bradshaw³, G.L. Gregory ${ }^{4}$, \\ G.W. Sachse ${ }^{4}$, and D.R. Blake ${ }^{5}$
}

\begin{abstract}
We quantify the tropospheric ozone budget over remote high northern latitudes in summer using chemical and meteorological measurements between 0 and $6-\mathrm{km}$ made during the summer of 1990 Arctic Boundary Layer Expedition (ABLE 3B). We include all components of the ozone budget, both sinks (in situ photochemical loss and deposition); and sources (in situ photochemical production, advection of pollution ozone into the region, production in biomass wildfire plumes, and downwards transport from the upper troposphere/stratosphere). In situ production and loss of ozone are calculated with a photochemical model. The net influx of pollution ozone from North America and Eurasia is estimated from the average enhancement ratio of $\Delta \mathrm{O}_{3} / \Delta \mathrm{C}_{2} \mathrm{Cl}_{4}$ observed in pollution plumes and scaled by the net influx of $\mathrm{C}_{2} \mathrm{Cl}_{4}$. The contribution of ozone produced in biomass wildfire plumes is estimated from the average enhancement ratio of $\Delta \mathrm{O} 3 / \Delta \mathrm{CO}$ in aged fire plumes. Regional photochemical production and loss in the $0-6 \mathrm{~km}$ column are found to be approximately equal; hence, net photochemical production is near zero. However, when ozone production and loss terms are separated, we find that dispersed in situ photochemical production driven by background NO levels ( $5-10 \mathrm{pptv}$ ) is the largest source term in the ozone budget (62\%). Influx of stratospheric ozone is of secondary importance $(27 \%)$. long-range transport of pollution ozone makes a small contribution (9\%), and photochemical production of ozone within biomass wildfire plumes is a relatively negligible term $(2 \%)$ in the budget. Biomass fires and transport of anthropogenic pollution into the region may however have a major effect on the ozone budget through enhancement of background $\mathrm{NO}$, mixing ratios which increase dispersed photochemical production. Using a 1-D time-dependent photochemical model between 0 and $6 \mathrm{~km}$, we obtain good agreement between the observed and model-generated vertical ozone profiles. We find that in situ photochemistry within the $0-6 \mathrm{~km}$ column accounts for nearly $90 \%$ of the ozone mixing ratio within the boundary layer, while above $5 \mathrm{~km}$ it accounts for only about $40 \%$. Although photochemical production of ozone within the $0-6 \mathrm{~km}$ column is larger than the other source terms combined, the 1-D model results indicate that influx from above is necessary to account for the observed increase in ozone mixing ratios with altitude.
\end{abstract}

\section{Introduction}

Ozone concentrations in industrialized regions of the northern hemisphere in summer have increased substantial-

\footnotetext{
'Department of Earth and Planetary Sciences and Division of Applied Science, Harvard University, Cambridge, Massachusetts.

2 Now at Department of Geology and Geophysical Sciences, Princeton University, Princeton, New Jersey.

${ }^{3}$ School of Earth and Atmospheric Science, Georgia Institute of Technology, Atlanta, Georgia.

${ }^{4}$ NASA Langley Research Center, Hampton, Virginia.

${ }^{5}$ Department of Chemıstry, University of Californı at Irvine, Irvine. Calıfornia.
}

Copyright 1996 by the American Geophysical Union.

Paper number 95JD03224.

0148-0227/96/95JD-03224\$05.00 ly in the past century [Logan, 1985; Intergovernmental Panel on Climate Change, 1990; Staehelin et al., 1994]; however, the global extent of human influence on tropospheric ozone remains unclear. A better understanding of the relative magnitude of sources of tropospheric ozone is crucial because ozone plays a central role in regulating the oxidizing capacity and hence the chemical composition of the lower atmosphere. Photolysis of ozone produces $\mathrm{O}\left({ }^{1} D\right)$, which then reacts with water vapor to form the hydroxyl radical $(\mathrm{OH})$. The hydroxyl radical is the primary oxidant for the removal of a variety of atmospheric pollutants and greenhouse gases, including $\mathrm{CO}, \mathrm{CH}_{4}$, other nonmethane hydrocarbons (NMHCs), and hydrohalocarbons (HCFCs). Ozone itself absorbs infrared radiation and is a greenhouse gas in the upper troposphere [Lacis et al., 1990]. In addition, ozone is an oxidant which has detrimental effects on vegetation and human health. For all the above reasons, it is critical to understand what controls the ozone budget and how human activities may perturb it. 
The distribution of tropospheric ozone is determined by a complex interplay of chemical and dynamical processes. Ozone enters the troposphere from the stratosphere, is advected from one region of the troposphere to another, and is produced within the troposphere by photochemical oxidation of $\mathrm{CO}$ and hydrocarbons in the presence of nitrogen oxides $\left(\mathrm{NO}_{r}=\mathrm{NO}+\mathrm{NO}_{2}\right)$. Ozone is lost via photolysis, reactions with radicals, and deposition to the Earth's surface. The lifetime of ozone in the troposphere varies from days to months, and hence ozone concentrations vary with latitude, altitude and season [Logan, 1985].

There is a long-standing debate regarding the relative importance of stratospheric and photochemical sources of ozone in the troposphere. Levy et al. [1985] summarized the literature supporting the view that tropospheric ozone concentrations are primarily controlled by transport from the stratosphere and surface destruction. Calculations conducted by Levy et al. [1985] using a general circulation/transport model without chemistry found that their simulation of tropospheric ozone was in general agreement with observations. They did, however, report evidence for significant production in the troposphere at latitudes north of $40^{\circ} \mathrm{N}$. Other authors have supported the view that the dominant source of tropospheric ozone is photochemical rather than stratospheric, at least on the scale of the northern hemisphere [Fishman et al., 1979; Liu et al., 1980; Chameides and Tan, 1981; Logan et al., 1981; Liu et al., 1987]. This early work, however, was hampered by the paucity of data for $\mathrm{NO}_{\lambda}$, the limiting precursor for ozone formation in the troposphere. A large number of measurements of $\mathrm{NO}_{x}$ mixing ratios have recently been compiled from various regions of the world [Carroll \& Thompson, 1995]. Photochemical model studies based on these measurements indicate that ozone production in the remote troposphere is sufficiently large to cancel chemical loss, resulting in either a small net production or a small net loss of ozone [Chameides et al., 1989; Chameides et al., 1990; Jacob et al., 1992a; Liu et al., 1992].

We present here an analysis of the summertime sources and sinks of tropospheric ozone in remote high northern latitudes. Our analysis uses chemical and meteorological data collected during the summer of 1990 from aircraft flights over Subarctic eastern Canada as part of the Arctic Boundary Layer Expedition 3B (ABLE 3B). This region is of particular interest because transport from the stratosphere to the troposphere is particularly strong at high northern latitudes [Danielsen, 1968; Shapiro, 1980; Shapiro et al., 1987], and because the region is downwind of polluted continents and therefore receives an influx of anthropogenic $\mathrm{O}_{3}$ and $\mathrm{NO}_{4}$ [Jacob et al., 1993; Bakwin et al., 1994]. Extensive biomass wildfires, which supply an additional source of $\mathrm{NO}_{x}[$ Singh et al., 1994; Sandholm et al., 1994; Talbot et al., 1994], also take place in the region during the summer [Stocks, 1991]. Hence conditions may exist for both highly efficient photochemical production of ozone and a strong stratospheric influx.

Previous analyses of the ABLE 3B data concluded that ozone distributions over Subarctic eastern Canada are im- pacted by long-range transport of urban pollution, forest fire emissions, sporadic encounters with tropical air and influx from the stratosphere [Anderson et al., 1994; Browell et al., 1994; Talbot et al., 1994]. These influences have clear signatures and are hence directly detectable in the data. Dispersed in situ photochemical production of ozone within the high northern latitude troposphere driven by background NO, levels may also be important but is harder to detect. Our inclusion of a modeling component permits a quantification of this source. As shown below, we find that dispersed in situ photochemical production provides the dominant source of tropospheric ozone in the ABLE 3B region and, we argue, more generally at high northern latitudes in summer. We find influx of stratospheric ozone to be ol secondary importance, long-range transport of pollution ozone to make a small contribution, and photochemical production of ozone within biomass wildfire plumes to be a relatively negligible term in the budget.

This paper is divided into five sections. Section 2 provides an overview of the observations used in the analysis. Section 3 describes the approach used to evaluate the budget of tropospheric ozone north of $45^{\circ} \mathrm{N}$ on the basis of the ABLE 3B measurements. Section 3 independently quantifies the different ozone sources (in situ photochemical production, influx of midlatitude pollution, local production within biomass wildfire plumes, and influx from the upper troposphere/stratosphere) and ozone sinks (in situ photochemical loss and deposition). Section 4 is a discussion of results including the derived ozone budget and an illustrative one-dimensional (1-D) model assessment, and section 5 is a summary of the analysis.

\section{Observations}

The ABLE 3B made chemical and meteorological measurements during aircraft flights over eastern Canada $\left(45^{\circ}\right.$ $63^{\circ} \mathrm{N}$ latitude, $50^{\circ}-106^{\circ} \mathrm{W}$ longitude, and 0-6 $\mathrm{km}$ altitude) during July and August 1990 [Harriss et al., 1994a]. Figure 1 is a map of the experimental region. Species measured aboard the aircraft included $\mathrm{O}_{3}, \mathrm{NO}, \mathrm{NO}_{2}$, total reactive odd-nitrogen $\left(\mathrm{NO}_{\mathrm{y}}\right)$, peroxyacetyl nitrate (PAN), $\mathrm{CO}, \mathrm{CO}_{2}$, nonmethane hydrocarbons (NMHCs), UV radiation, $\mathrm{H}_{2} \mathrm{O}$, and several chlorinated compounds of exclusively industrial origin including $\mathrm{C}_{2} \mathrm{Cl}_{4}, \mathrm{CH}_{3} \mathrm{CCl}_{3}$, and CFC-11. Our analysis of biomass wildfire and pollution plumes uses the archived data from all flights shown in Figure 1, including transit flights over the northeastern United States. Our photochemical calculations use a merged data base of 579 points collected entirely within eastern Canada (missions 2-20) that was created by averaging the concentration of measured species over the 90 second intervals for which NO measurements were available. Measurements cover from 0800-1900 local solar time (defined as maximum solar elevation at noon).

One objective of the ABLE 3B expedition was to characterize the composition of biomass wildfire and pollution plumes. Hence the database is biased towards more polluted air [Harriss et al., 1994b; Browell et al., 1994]. To remove 
ABLE-3B Filght Paths

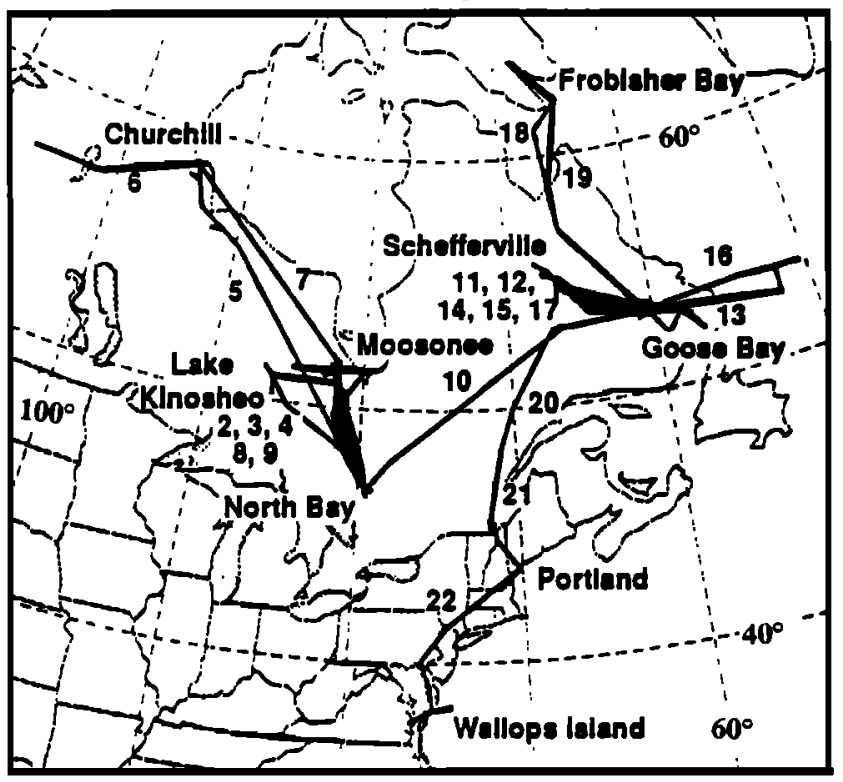

Figure 1. Map of Arctic Boundary Layer Expedition (ABLE 3B) aircraft flight paths used in analysis. Numbers on the map identify individual flights. Adapted from Shipham et al. [1994].

this bias and define a representative background for the regional atmosphere, we compare the probability distribution lunction (pdf) of $\mathrm{CO}$ mixing ratios from the merged database to a Gaussian distribution (Figure 2a). We define the regional background as the approximately normal population represented by $\mathrm{CO}$ levels between 80 and $110 \mathrm{ppbv}$ ( 299 points) which thus excludes encounters with tropical air as well as pollution and biomass wildfire plumes. Our definition of the regional background is consistent with long-term measurements of $\mathrm{CO}$ at Barrow, Alaska, which indicate a mean concentration of $97 \pm 9$ ppbv for July - August 1990 (P. Novelli, personal communication, 1995). Figure $2 b$ shows the pdf of NO concentrations for the entire database and for the data subset defined as background air. Our definition of background air effectively excludes high- $\mathrm{NO}_{\mathrm{x}}$ plumes.

To characterize the regional composition of the troposphere, mean mixing ratio versus altitude profiles for $\mathrm{O}_{3}$, $\mathrm{CO}, \mathrm{NO}, \mathrm{C}_{2} \mathrm{H}_{4}, \mathrm{C}_{2} \mathrm{H}_{6}, \mathrm{C}_{3} \mathrm{H}_{8}$, isoprene, and $\mathrm{C}_{2} \mathrm{Cl}_{4}$ are shown in Figure 3. To compensate for uneven sampling throughout the day of species with a diurnal variation in concentration, we obtained these profiles by binning the data into $1-\mathrm{km}$ altitude bins and then dividing the data within each altitude bin into 2-hour time intervals symmetrically around 12 noon. Morning/evening folding was used to compensate for a lack of early morning measurements. The means of each 2 - hour time interval within each $1-\mathrm{km}$ altitude bin were averaged to yield the profile of a given species with altitude. For $\mathrm{O}_{3}, \mathrm{CO}, \mathrm{NO}$, and $\mathrm{C}_{2} \mathrm{Cl}_{4}$ two profiles are presented; the first (dashed line) includes all the data, the second (solid line) includes only the regional background air. For the NMHCs, only data from background air are shown.

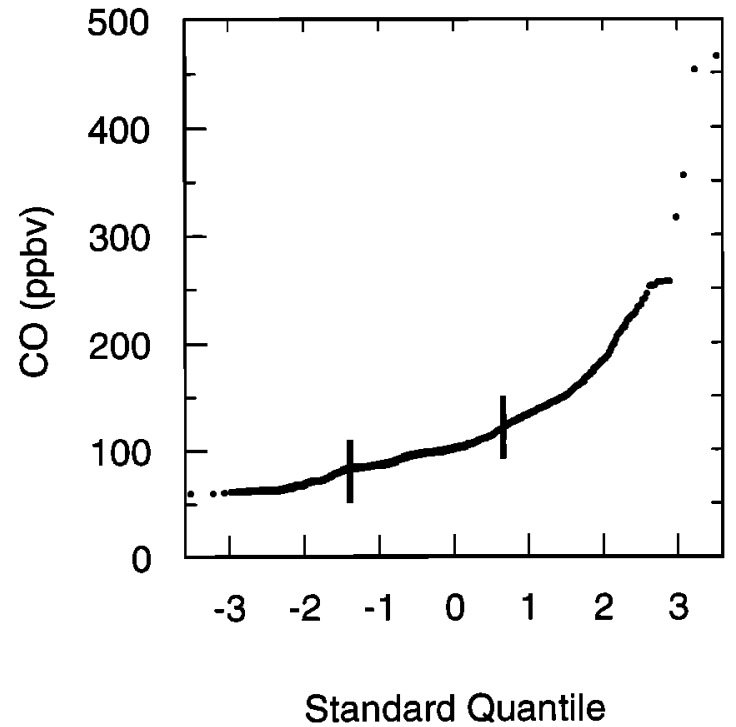

Figure 2a. Probability distribution function of $\mathrm{CO}$ concentrations in ABLE 3B plotted against the normal (Gaussian) distribution. The $x$-axis gives quantiles of standard normal such that \pm 1 represents $\pm 1 \sigma$. A population of points with a normal distribution appears as a straight line. $\mathrm{CO}$ concentrations between 80 and $110 \mathrm{ppbv}$ (vertical bars) are taken as representative of the regional atmospheric background.

Similar chemical and meteorological measurements to $A B L E 3 B$ were made during $A B L E 3 A$ in the summer of 1988 over Alaska [Harriss et al., 1992]; however, ABLE 3A was not attempting to characterize biomass burning or pollution plumes. The chemical composition of the ABLE $3 \mathrm{~A}$ region is similar to the background air in ABLE 3B as defined here. This similarity suggests that background air in the Arctic troposphere in summer has a relatively homoge-

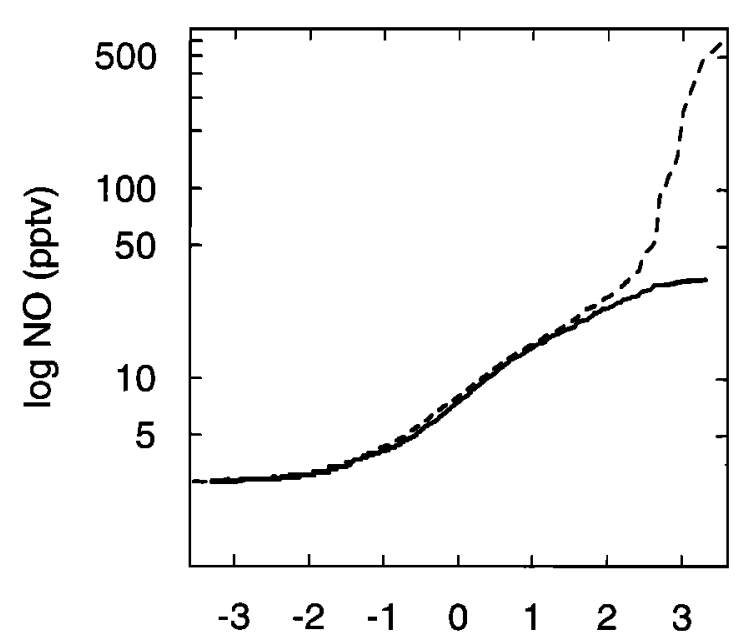

\section{Standard Quantile}

Figure 2b. Probability distribution function of NO concentrations for the entire ABLE 3B merged data set (dashed line) and for the data subset representative of the regional background as defined by $80<\mathrm{CO}<110 \mathrm{ppbv}$ (solid line). 

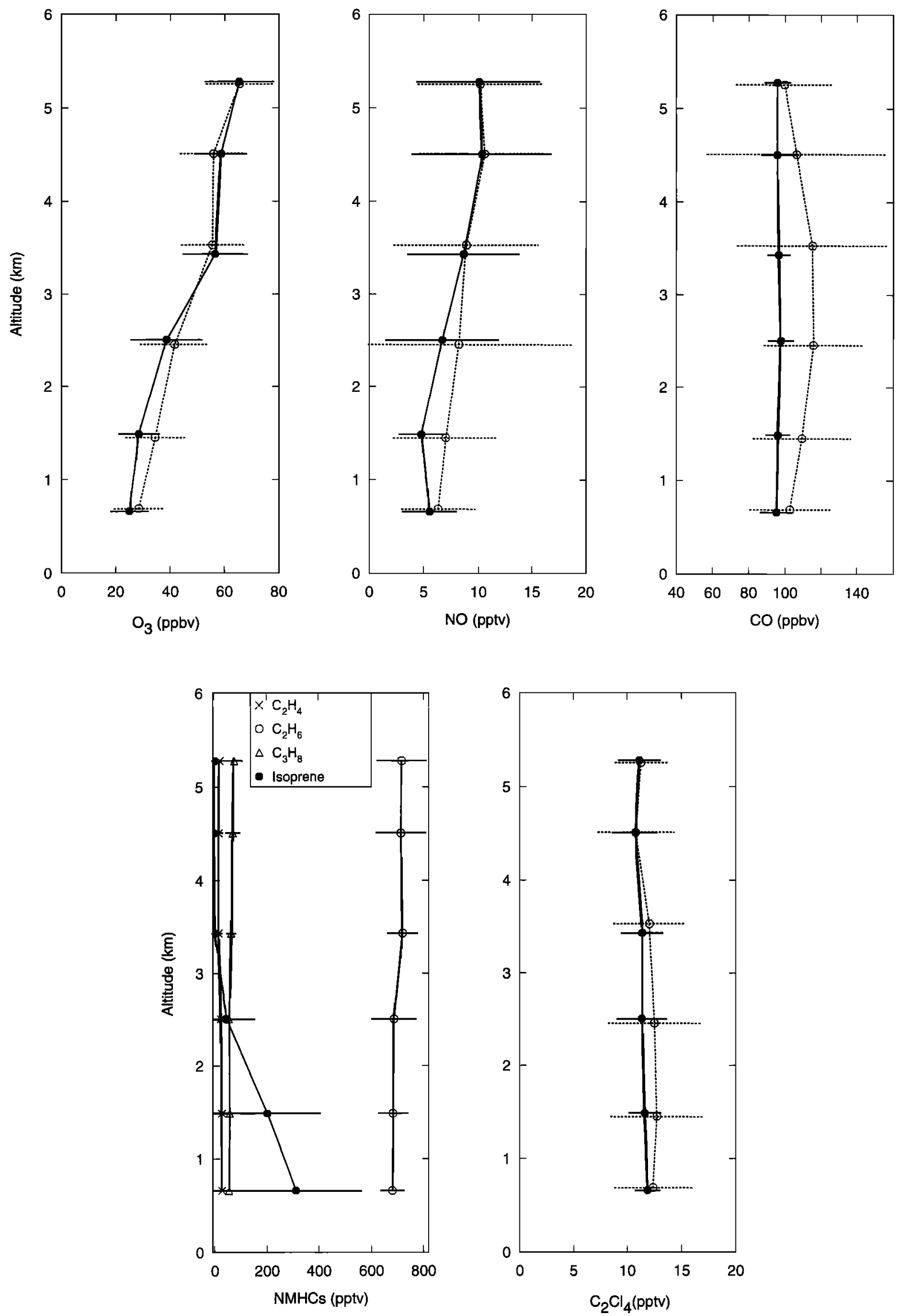

Figure 3. Mean daytime (4-20 solar time) mixing ratio profiles in ABLE 3B merged data set. Dashed lines include all data, solid lines include only the data subset with $80<\mathrm{CO}<110 \mathrm{ppbv}$ which defines regional background air. Horizontal bars indicate one standard deviation from the mean. 
neous composition due in part to the jet stream which isolates it from the more polluted midlatitudes [Barrie, 1986].

\section{Regional Ozone Budget}

We focus our analysis on a "remote high northern latitudes" region defined as the circumpolar cap north of $45^{\circ} \mathrm{N}$, excluding industrial areas of northern Europe, and extending from the surface to 6-km altitude (ceiling of the ABLE $3 \mathrm{~B}$ aircraft). The size of this domain was chosen to accommodate the relatively long lifetime of ozone (averaging 26 days, as discussed in section 4). The regional ozone budget we calculate separates ozone sources (in situ photochemical production, advection of pollution ozone from midlatitude continents, local production within biomass wildfire plumes, and influx from the upper troposphere/stratosphere) from ozone sinks (in situ photochemical loss and deposi(ion). Figure 4 is a schematic of the ozone source and sink terms contributing to the budget. Quantitative estimates for each of these terms are presented below.

\section{Photochemistry}

The effect of regional photochemistry on ozone is defined by the production and loss rates of the odd oxygen $\left(\mathrm{O}_{\mathrm{r}}\right)$ family $\left(\mathrm{O}_{\mathrm{r}} \equiv \mathrm{O}_{3}+\mathrm{O}\left({ }^{1} D\right)+\mathrm{O}\left({ }^{3} P\right)+\mathrm{NO}_{2}+2 \mathrm{NO}_{3}+3 \mathrm{~N}_{2} \mathrm{O}_{5}+\right.$ PAN). This definition accounts for the rapid cycling between ozone and other forms of $O_{x}$. PAN is included in this definition of $\mathrm{O}$, to account for the rapid cycling of PAN and $\mathrm{NO}_{2}$ at the warm temperatures of the lower troposphere in summer.

The only significant source of $\mathrm{O}_{\mathbb{1}}$ is by reaction (1):

$$
\mathrm{RO}_{2}+\mathrm{NO}->\mathrm{RO}+\mathrm{NO}_{2}
$$

where $\mathrm{RO}_{2}$ represents the ensemble of peroxy radicals produced by oxidation of $\mathrm{CO}$ and hydrocarbons. Loss of $\mathrm{O}_{x}$ is primarily by reactions (2)-(4):

$$
\mathrm{O}\left({ }^{1} D\right)+\mathrm{H}_{2} \mathrm{O} \rightarrow 2 \mathrm{OH}
$$$$
\mathrm{O}_{3}+\mathrm{OH} \rightarrow \mathrm{HO}_{2}+\mathrm{O}_{2}
$$

$$
\mathrm{O}_{3}+\mathrm{HO}_{2}>\mathrm{OH}+2 \mathrm{O}_{2}
$$

plus a minor sink from ozonolysis of olefins including isoprene.

Rawinsonde measurements made at the ABLE 3B surface site at Schefferville, Quebec (Figure 1), indicate a typical afternoon mixed layer depth of $2.25 \mathrm{~km}$ [Fitzjarrald and Moore, 1994] which is used in what follows to partition the boundary layer from the free troposphere. We calculate $O_{r}$ production and loss rates in the free troposphere using a zero-dimensional (0-D) instantaneous steady state (ISS) photochemical model applied to each regional background point in the merged ABLE 3B data set. For each point the 0D model uses as constraints the UV radiation flux measured by zenith and nadir Eppley radiometers, the observed temperature, dew point, altitude, and mixing ratios of $\mathrm{O}_{3}, \mathrm{CO}$, $\mathrm{NO}, \mathrm{C}_{1.7}$ alkanes, $\mathrm{C}_{2-3}$ alkenes, isoprene, benzene, toluene and acetone. It then solves the local chemical instantaneous steady state equations for radicals other than $\mathrm{NO}$, as well as for aldehydes, peroxides, ketones, $\mathrm{HNO}_{2}$, and $\mathrm{HNO}_{4}$. The $\mathrm{NO}_{2}$ measurement aboard the aircraft may have suffered from positive interference [Crawford et al., 1995] and we choose therefore to compute $\mathrm{NO}_{2}$ concentrations from the model. A comparison of measured versus modeled $\mathrm{NO}_{2}$ concentrations in ABLE 3B is given by Fan et al. [1994].

The photochemical mechanism is based on recent compilations of kinetic and product data [Atkinson, 1990; Atkinson

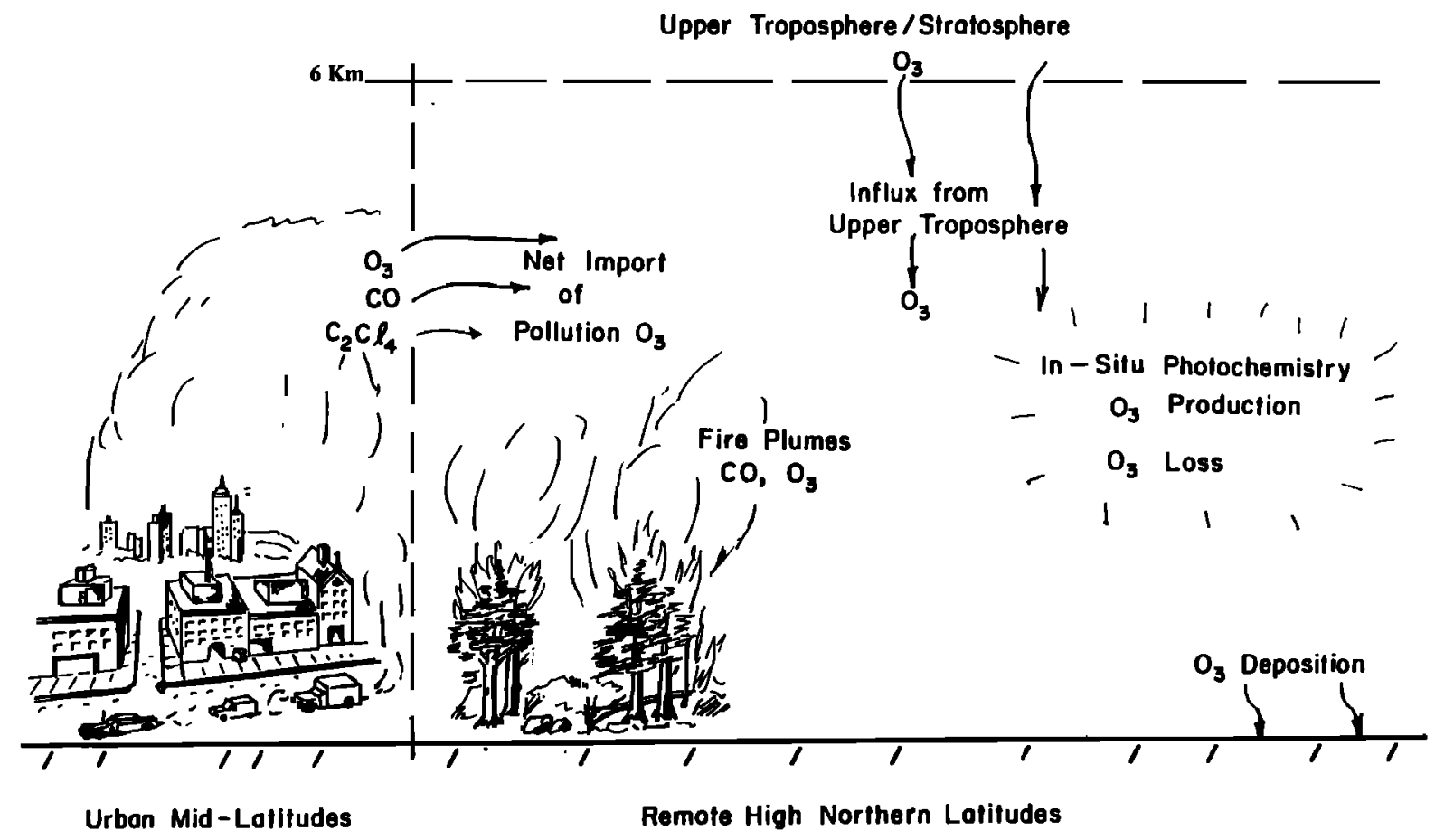

Figure 4. Schematic of the ozone budget for 0-6 km column at remote high northern latitudes. 
et al., 1992; DeMore et al., 1992; Tuazon and Atkinson, 1989,1990 a,b]. The $\mathrm{NO}_{2}$ photolysis rate coefficient, $J_{\mathrm{NO} 2}$, is obtained from the Eppley UV fluxes with the parameterization of Chameides et al. [1990]. Photolysis rate coefficients for other species are calculated using a six-stream radiative transfer code for the clear-sky, Rayleigh scattering atmosphere with zero surface albedo [Logan et al., 1981], and are then scaled by the ratio of $J_{\mathrm{NO2}}$ derived from the UV measurements to $J_{\mathrm{NO} 2}$ calculated with the code (the mean and standard deviation of $J_{\mathrm{NO} 2}$ (measured) $/ J_{\mathrm{NO} 2}$ (calculated) $=$ 1.1 \pm 0.3 ). The overhead ozone column used in the radiation calculation is obtained from daily Total Ozone Mapping Spectrometer (TOMS) satellite measurements on an approximately $1^{\circ} \times 1^{\circ}$ scale, and ranges from 290 to 360 Dobson units.

Greater accuracy in the photochemical model computation could be obtained by using a diel steady state (DSS) approach, where chemical steady state for a species is defined by the repeatability of the diel cycle in a time-dependent calculation. In a comparison of ISS and DSS approaches for computing ozone production in a point model, D. J. Jacob et al. (The origin of ozone and $\mathrm{NO}_{x}$ in the tropical troposphere: a photochemical analysis of aircraft observations over the South Atlantic basin, submitted to Journal of Geophysical Research, 1995) found agreement to within 10\% between the two approaches for 0800-1600 local solar time (ST). However, the ISS calculation underestimated ozone production at lower sun angles. In our data set, since nearly $75 \%$ of the daily total ozone production occurred between 0800 and 1600 ST as is indicated in Figure 5, underestimation of ozone production should be small.

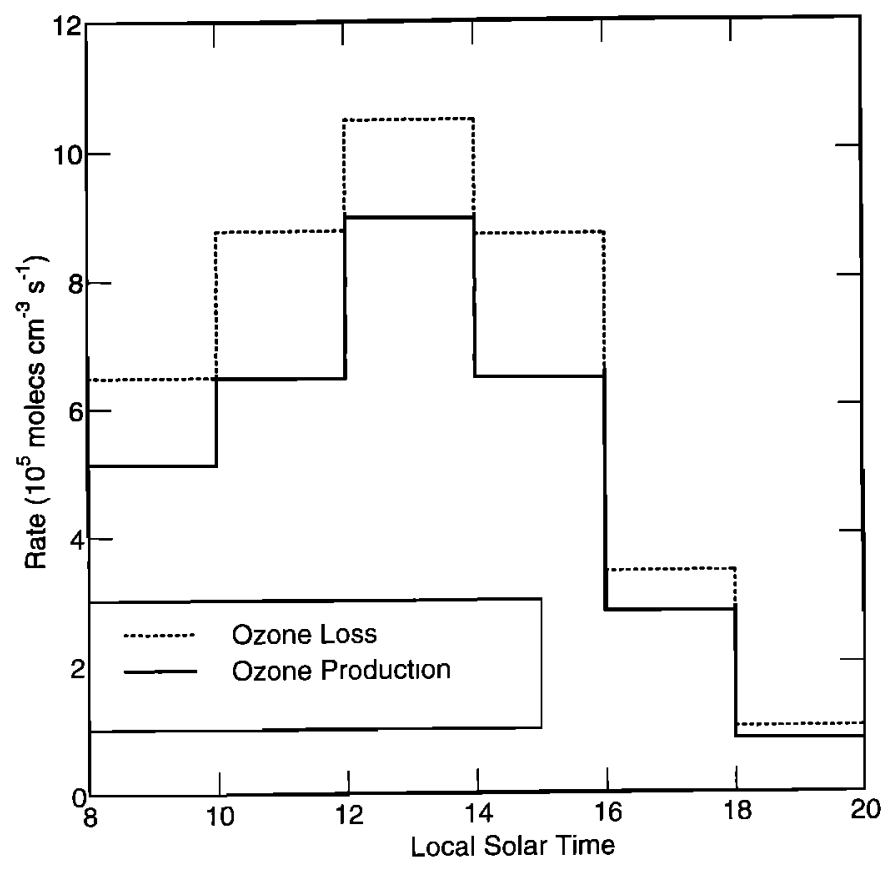

Figure 5. Diurnal cycle of ozone production and loss computed for background air $(80<\mathrm{CO}<110 \mathrm{ppbv})$ in the free troposphere $(2.25-6 \mathrm{~km})$.

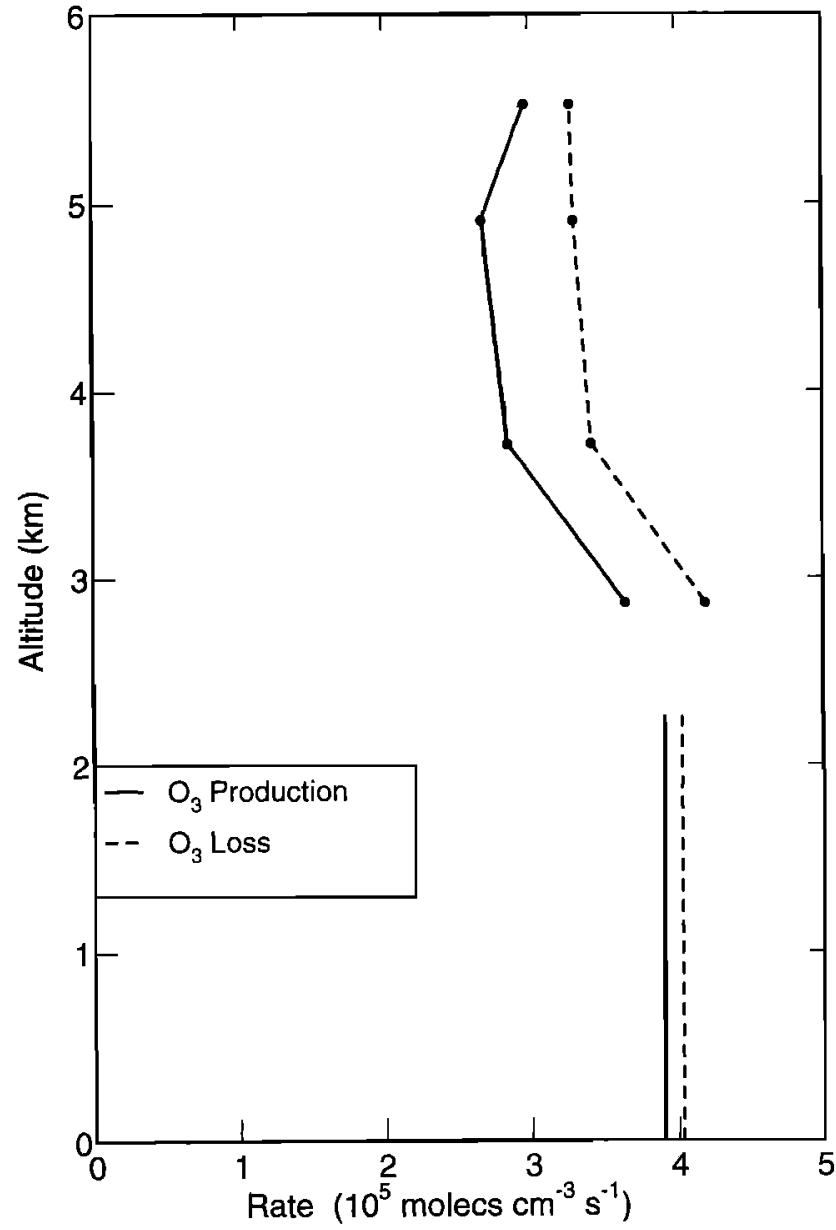

Figure 6. The 24-hour average ozone production and loss profiles (solid and dashed lines, respectively) computed for regional background air $(80<\mathrm{CO}<110 \mathrm{ppbv})$.

Results from the 0-D model for individual points in the free troposphere yield a collection of ozone production and loss rates. The resulting mean diurnal cycles of ozone production and loss are shown in Figure 5. To obtain regional 24-hour average ozone production and loss rates, we first binned the data into 1-km altitude bins. Within each altitude bin we divided the data into 2-hour intervals and took the mean of each time interval. The means of each 2-hour interval, with morning/evening folding used to compensate for lack of early morning measurements and with 8 hours of darkness assumed, were averaged to obtain the regional 24hour mean vertical profiles of ozone production and loss between 2.25-6 km shown in Figure 6. Integrating over the depth of the 2.25-6 km free troposphere column, we obtain regional ozone column production and loss rates of $11 \times$ $10^{10}$ molecules $\mathrm{cm}^{-2} \mathrm{~s}^{-1}$ and $14 \times 10^{10}$ molecules $\mathrm{cm}^{-2} \mathrm{~s}^{-1}$, respectively.

The ozone production rate is particularly sensitive to the NO mixing ratio, while the ozone loss rate is relatively insensitive to it [Fishman et al., 1979]. Any systematic offset in the NO measurement is believed to be less than 3 pptv [Sandholm et al., 1994]. We conducted an uncertainty anal- 
ysis on the ozone production rate by repeating the ensemble of point model calculations using measured concentrations of NO \pm 3 pptv. The resulting range in ozone production for the $2.25-6 \mathrm{~km}$ column is $8-14 \times 10^{10}$ molecules $\mathrm{cm}^{-2} \mathrm{~s}^{-1}$.

The 0-D modeling approach that we used for the free troposphere is inadequate in the boundary layer because of the importance of isoprene and its decomposition products in modifying ozone production and loss. Because the lifetime of isoprene is only a few hours while some of its oxidation intermediates have longer lifetimes, local steady state between isoprene concentrations sampled from the aircraft and isoprene oxidation products cannot be assumed. A more realistic approach, which we adopt here, uses a diel 1-D model for the boundary layer with isoprene emission as a boundary condition. The presence of isoprene and its oxidation products result in an increase in peroxy radical concentrations and hence in ozone production.

A full description of the 1-D boundary layer model is given by Fan et al. [1994]. The model input is obtained from ground-based and aircraft measurements made during spirals over an instrumented tower at Schefferville, Quebec (Figure 1) on August 7, 1990. These measurements were typical of the regional background air as previously defined. The 24-hour average isoprene emission flux is specified at $6.1 \times 10^{10}$ molecules $\mathrm{cm}^{-2} \mathrm{~s}^{-1}$ to match the isoprene concentrations observed in the aircraft spirals. The resulting 24hour mean ozone production rate for the boundary layer column $(0-2.25 \mathrm{~km})$ is $9 \times 10^{10}$ molecules $\mathrm{cm}^{-2} \mathrm{~s}^{-1}$ with an estimated uncertainty based on NO \pm 3 pptv of $7-11 \times 10^{10}$ molecules $\mathrm{cm}^{-2} \mathrm{~s}^{-1}$. The 24-hour mean ozone loss rate in the column is also approximately $9 \times 10^{10}$ molecules $\mathrm{cm}^{-2} \mathrm{~s}^{-1}$. Summing the free troposphere and boundary layer columns yields 24-hour mean regional ozone production and loss rates for the $0-6 \mathrm{~km}$ column of $20(15-25) \times 10^{10}$ molecules $\mathrm{cm}^{-2} \mathrm{~s}^{-1}$, and $23 \times 10^{10}$ molecules $\mathrm{cm}^{-2} \mathrm{~s}^{-1}$, respectively. Since our primary intent is to compare the magnitude of source terms, no attempt is made to calculate uncertainties in loss rates.

\section{Advection of Midlatitude Pollution Ozone}

To estimate the contribution from the long-range transport of urban/industrial midlatitude pollution ozone to the ozone budget at remote high northern latitudes, we assume that the chemical signatures of the anthropogenic plumes sampled during the expedition are representative of pollution advected to high northern latitudes. Following Wofsy et al. [1994], we identify anthropogenic plumes in the ABLE 3B data set by enhancements in $\mathrm{C}_{2} \mathrm{Cl}_{4}$ mixing ratios above background levels simultaneously with enhancements in other halocarbons, $\mathrm{CO}, \mathrm{C}_{2} \mathrm{H}_{2}$, and $\mathrm{NO}_{-} \mathrm{C}_{2} \mathrm{Cl}_{4}$ is a particularly good indicator of anthropogenic pollution because emission of $\mathrm{C}_{2} \mathrm{Cl}_{4}$ occurs primarily in urban and industrial regions during its use as a dry cleaning and metal degreasing solvent and because it has no natural sources. To obtain a characteristic enhancement of $\Delta \mathrm{O}_{3} / \Delta \mathrm{C}_{2} \mathrm{Cl}_{4}$ for midlatitude pollution ( $\Delta$ gives the enhancement in a pollution plume above the local background level), we multiply the mean an- thropogenic pollution enhancement ratio $\Delta \mathrm{CO} / \Delta \mathrm{C}_{2} \mathrm{Cl}_{4}=$ 3800 molecules/molecule observed in ABLE 3B [Wofsy et al., 1994] by the mean $\Delta \mathrm{O}_{3} / \Delta \mathrm{CO}$ observed in pollution plumes. We choose not to calculate $\Delta \mathrm{O}_{3} / \Delta \mathrm{C}_{2} \mathrm{Cl}_{4}$ directly, as the $\Delta \mathrm{C}_{2} \mathrm{Cl}_{4}$ signal above background mixing ratios can be difficult to quantify in individual plumes. $\Delta \mathrm{O}_{3} / \Delta \mathrm{C}_{2} \mathrm{Cl}_{4}$ is then scaled by the net flux of $\mathrm{C}_{2} \mathrm{Cl}_{4}$ advected from midlatitudes and Eurasia $\left(\Phi_{\mathrm{C}_{2} \mathrm{Cl}_{4}}\right)$ to obtain the corresponding net flux of pollution $\mathrm{O}_{3}\left(\Phi_{\mathrm{O}_{3}}\right)$ :

$$
\begin{aligned}
\Phi_{O_{3}} & =\Phi_{C_{2} C_{4}}\left(\frac{\Delta \mathrm{O}_{3}}{\Delta \mathrm{C}_{2} \mathrm{Cl}_{4}}\right) \\
& =\Phi_{C_{2} C_{4}}\left(\frac{\Delta \mathrm{O}_{3}}{\Delta \mathrm{CO}}\right)_{\text {mean }}\left(\frac{\Delta \mathrm{CO}}{\Delta \mathrm{C}_{2} \mathrm{Cl}_{4}}\right)_{\text {mean }}
\end{aligned}
$$

The above expression is based on a simple model viewing the high northern latitudes as a well-mixed box. Air flowing from mid-latitudes into this box contains background mixing ratios of compounds $A$ and $B\left(A_{b}, B_{b}\right)$ plus pollution enhancements $(\Delta A, \Delta B)$. Air flowing out of the box contains background mixing ratios $\left(A_{b}, B_{b}\right)$. We assume that background concentrations at mid latitudes and high latitudes are the same. Thus the net flux of $\mathrm{A}$ into the high latitudes box is given by: $\Phi_{\mathrm{A}}=F_{\mathrm{In}}\left(A_{b}+\Delta A\right)-F_{\mathrm{our}} A_{b}=F \Delta A$. Here $F_{\mathrm{In}}$ and $F_{\text {out }}$ are the air mass fluxes in and out of the box, respectively $\left(F_{\mathrm{in}}=F_{\text {oul }}=F\right)$. Similarly for $B: \Phi_{\mathrm{B}}=F \Delta B$. This implies: $\Phi_{\mathrm{B}}=\Phi_{\mathrm{A}}(\Delta B / \Delta A)$. We can then obtain equation (1) by setling $B=\mathrm{O}_{3}$ and $A=\mathrm{C}_{2} \mathrm{Cl}_{4}$.

The net flux of $\mathrm{C}_{2} \mathrm{Cl}_{4}, \Phi_{\mathrm{C}_{2} \mathrm{Cl}_{4}}$ (molecules $\mathrm{cm}^{-2} \mathrm{~s}^{-1}$ ) from mud-latitudes and Eurasia to the remote high northern latitudes region is estimated from the ABLE $3 \mathrm{~B}$ data by using a mass balance approach for the $0-6 \mathrm{~km}$ column adapted lrom Wofsy et al., [1994]:

$$
\Phi_{\mathrm{C}_{2} \mathrm{Cl}_{4}}=\left(k\left[\mathrm{C}_{2} \mathrm{Cl}_{4}\right][\mathrm{OH}]+\frac{\partial\left[\mathrm{C}_{2} \mathrm{Cl}_{4}\right]}{\partial t}\right) \Delta z
$$

The first term on the right of equation (2) represents the pholochemical loss of $\mathrm{C}_{2} \mathrm{Cl}_{4}$ in the region. $k=1.3 \times 10^{-13} \mathrm{~mol}-$ ecules $\mathrm{cm}^{-3} \mathrm{~s}^{-1}$ is the rate constant for the reaction of $\mathrm{OH}$ with $\mathrm{C}_{2} \mathrm{Cl}_{4}$ at $280 \mathrm{~K}$, the mean temperature of the $0-6 \mathrm{~km}$ column. $[\mathrm{OH}]=1 \times 10^{6}$ molecules $\mathrm{cm}^{-3}$ is the 24 hour mean concentration calculated in the 0 -D model for the region. $\left[\mathrm{C}_{2} \mathrm{Cl}_{4}\right]=12 \mathrm{ppt}$ is the mean background concentration measured in ABLE 3B (this concentration is independent of altitude, as shown in Figure 3). A mean 0-6 km column air density of $1.9 \times 10^{19}$ molecules $\mathrm{cm}^{-3}$ is used to convert from pptv giving a photochemical loss rate of 29.4 molecules $\mathrm{cm}^{-3} \mathrm{~s}^{-1}$. The second term, $\partial\left[\mathrm{C}_{2} \mathrm{Cl}_{4}\right] / \partial \mathrm{t}=-4.4$ molecules $\mathrm{cm}^{-3} \mathrm{~s}^{-1}$, is the rate of change in concentration in the ABLE $3 \mathrm{~B}$ region during the July-August observation period [Wofsy et al., 1994]; it amounts to less than $15 \%$ of the first term. Multiplying by the depth of the $0-6 \mathrm{~km}$ column $(\Delta z)$, we obtain $\Phi_{\mathrm{C}_{2} \mathrm{Cl}_{4}}=1.5 \times 10^{7}$ molecules $\mathrm{cm}^{-2} \mathrm{~s}^{-1}$.

Pollution plumes used to derive the $\Delta \mathrm{O}_{3} / \Delta \mathrm{CO}$ enhancement ratio for equation (1) are required to satisfy three cri- 


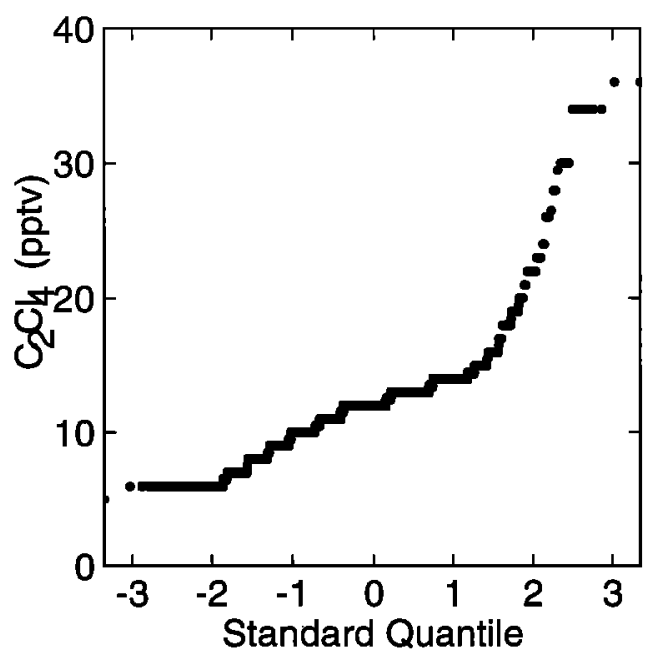

Figure 7. Probability distribution function of $\mathrm{C}_{2} \mathrm{Cl}_{4}$ concentrations in ABLE 3B.

teria. First, they must show a clear influence from combustion, evidenced by enhancements in $\mathrm{CO}$ and acetylene. Second, they must be clearly anthropogenic, evidenced by $\mathrm{C}_{2} \mathrm{Cl}_{4}$ enhancements of at least 2.5 pptv or $\mathrm{CH}_{3} \mathrm{CCl}_{3}$ enhancements of at least 5 pptv above local background levels. As shown by the pdf of $\mathrm{C}_{2} \mathrm{Cl}_{4}$ in Figure 7, a 2.5 pptv enhancement above background is already indicative of a pollution plume. Third, the $\mathrm{NO}_{x} / \mathrm{NO}_{1}$ ratio in the plumes must be less than 0.2 , indicating that the primary ozone production potential of the plume has been nearly exhausted [Trainer et al., 1993; Chin et al., 1994]. Table 1 is a compilation of enhancement ratios for the anthropogenic pollution plumes in ABLE 3B meeting the three above criteria. The average enhancement ratio is: $\Delta \mathrm{O}_{3} / \Delta \mathrm{CO}=0.5 \pm$ 0.5 molecules/molecule.

Figure 8 shows sample plots from a spiral on mission 6 . We diagnose the plume at $5 \mathrm{~km}$ as anthropogenic due to strong enhancements over local background concentrations in $\mathrm{CO}, \mathrm{C}_{2} \mathrm{H}_{2}, \mathrm{NO}_{y}, \mathrm{C}_{2} \mathrm{Cl}_{4}$ and $\mathrm{CH}_{3} \mathrm{CCl}_{3}$. However, we diagnose a biomass wildfire origin for the plume at $3 \mathrm{~km}$ due to strong enhancements in $\mathrm{CO}, \mathrm{C}_{2} \mathrm{H}_{2}$, and $\mathrm{NO}_{y}$, but without enhancements in either $\mathrm{C}_{2} \mathrm{Cl}_{4}$ or $\mathrm{CH}_{3} \mathrm{CCl}_{3}$. This determination is consistent with back trajectories [Shipham et al., 1994].
Using equation (1) and values calculated as described above for $\Phi_{\mathrm{C}_{2} \mathrm{Cl}_{4}}, \Delta \mathrm{O}_{3} / \Delta \mathrm{CO}$, and $\Delta \mathrm{CO} / \Delta \mathrm{C}_{2} \mathrm{Cl}_{4}$, we obtain an estimate for the net influx of urban/industrial ozone to the remote high northern latitudes of $\Phi_{\mathrm{O}_{3}}=3 \times 10^{10}$ molecules $\mathrm{cm}^{-2} \mathrm{~s}^{-1}$ within a range of $1-5 \times 10^{10}$ molecules $\mathrm{cm}^{-2} \mathrm{~s}^{-1}$.

\section{Biomass Burning Plumes}

Plumes which meet the combustion and aged criteria, but which show no enhancement in halocarbon concentrations are attributed to biomass wildfires. We scale up from the mean enhancement ratio $\left(\Delta \mathrm{O}_{3} / \Delta \mathrm{CO}\right)$ observed within aged wildfire plumes to the net contribution, $B_{\mathrm{O} 3}$, of these plumes to the regional ozone budget, using:

$$
B_{\mathrm{O}_{3}}=E_{\mathrm{CO}}\left(\frac{\Delta \mathrm{O}_{3}}{\Delta \mathrm{CO}}\right)_{\text {mean }}
$$

$E_{\mathrm{CO}}$ is the emission rate of $\mathrm{CO}$ from wildfires north of $45^{\circ} \mathrm{N}$ during July and August of 1990. A global database for biomass burning (J. A. Logan and R. Yevich, manuscript in preparation, 1995), gives an estimate of $260 \mathrm{Tg}$ for the mean quantity of biomass annually burned north of $45^{\circ} \mathrm{N}$ during the $1980 \mathrm{~s}$. We assume a $50 \%$ carbon content for biomass fuel [Stocks, 1991] and a mean emission ratio $\mathrm{CO} / \mathrm{C}=9.5 \%$ lor biomass fires [Ward and Hardy, 1991]. Statistics avai]able for Canada indicate that burning in July and August of 1990 represented $31 \%$ of the total mean area annually burned during the 1980s [Higgins and Ramsey, 1992]. We thus estimate $E_{\mathrm{CO}}=5 \times 10^{10}$ molecules $\mathrm{cm}^{-2} \mathrm{~s}^{-1}$ for the circumpolar cap north of $45^{\circ} \mathrm{N}$ during July and August of 1990.

Table 2 provides enhancement ratios of aged biomass wildfire plumes sampled in ABLE 3B. The mean enhancement of the nine plumes is $\Delta \mathrm{O}_{3} / \Delta \mathrm{CO}=0.1 \pm 0.2$ molecules/ molecule. $\Delta \mathrm{O}_{3} / \Delta \mathrm{CO}$ enhancements in the aged wildfire plumes are approximately one-fifth the $\Delta \mathrm{O}_{3} / \Delta \mathrm{CO}=0.5 \pm$ 0.5 molecules/molecule observed in aged pollution plumes. This is likely due to the lower $\mathrm{NO}_{\mathbf{x}} / \mathrm{CO}$ emission ratio in biomass fires than in urban/industrial pollution [Jacob et al., 1992a]. Similar $\Delta \mathrm{O}_{3} / \Delta \mathrm{CO}$ enhancement ratios have been previously reported for biomass burning plumes sampled in

Table 1. Concentration Enhancements $(\Delta)$ in Aged Anthropogenic Pollution Plumes

\begin{tabular}{|c|c|c|c|c|c|c|c|}
\hline Mission & $\begin{array}{c}\text { Plume } \\
\text { Altitude, } \\
\text { km }\end{array}$ & $\begin{array}{l}\Delta \mathrm{O}_{3}, \\
\mathrm{ppbv}\end{array}$ & $\begin{array}{l}\Delta \mathrm{CO}, \\
\mathrm{ppbv}\end{array}$ & $\begin{array}{c}\Delta \mathrm{NO}_{\mathfrak{1}} \\
\text { pptv }\end{array}$ & $\begin{array}{c}\Delta \mathrm{NO}_{1} \\
\text { pptv }\end{array}$ & $\begin{array}{l}\triangle \mathrm{NO}_{1}{ }^{\prime} \\
\Delta \mathrm{NO}_{1}\end{array}$ & $\Delta \mathrm{O}_{3} / \Delta \mathrm{CO}$ \\
\hline 6 & 5.0 & 16 & 150 & $\bar{U}$ & 2100 & $\mathrm{U}$ & 0.11 \\
\hline 10 & 3.3 & 21 & 40 & 30 & 150 & 0.2 & 0.53 \\
\hline 16 & 3.2 & 4 & 24 & 10 & 200 & 0.05 & 0.17 \\
\hline 16 & 4.5 & 13 & 10 & 28 & 250 & 0.11 & 1.3 \\
\hline \multirow[t]{2}{*}{22} & 3.0 & 12 & 60 & 40 & 900 & 0.04 & 0.2 \\
\hline & & & & & & & $\begin{array}{c}0.5 \pm 0.5 \\
\text { (mean) }\end{array}$ \\
\hline
\end{tabular}



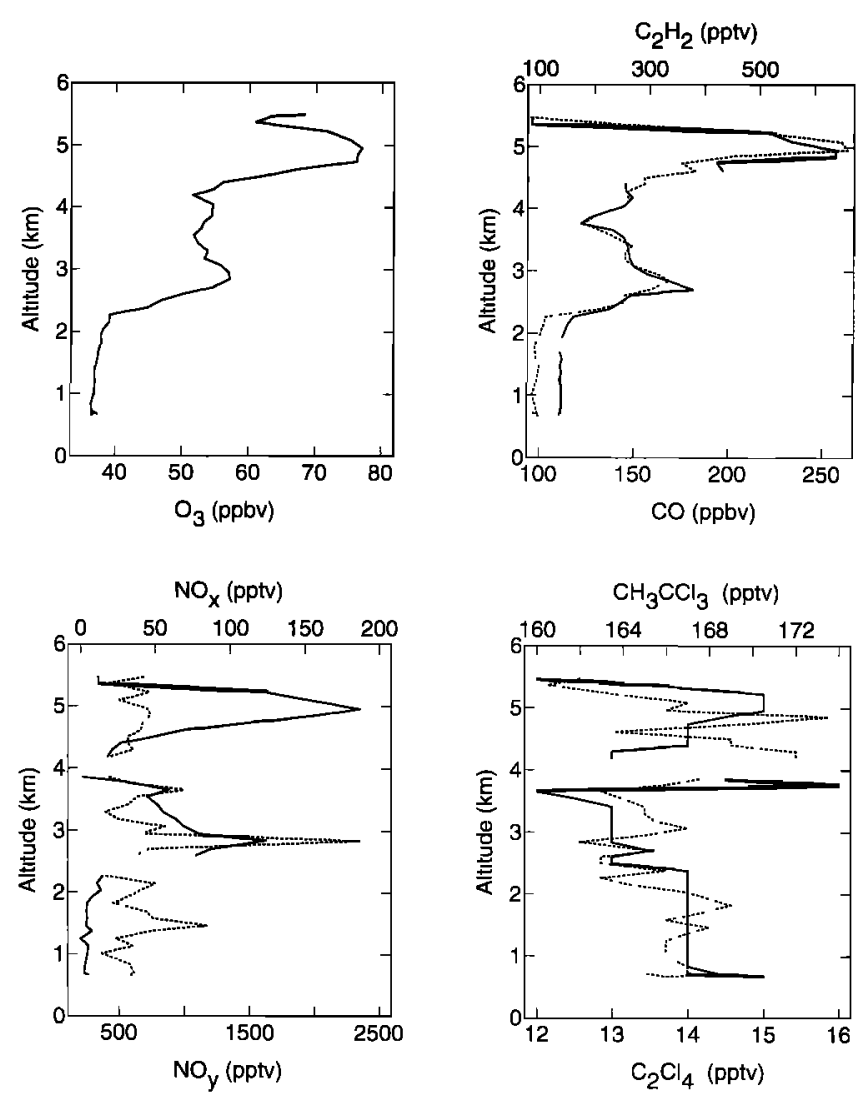

Figure 8. Vertical spiral from mission 6 on July 21, 1990 at $56^{\circ} \mathrm{N}, 105^{\circ} \mathrm{W}$. Concentrations of $\mathrm{O}_{3}, \mathrm{CO}, \mathrm{NO}_{\mathrm{y}}$ and $\mathrm{C}_{2} \mathrm{Cl}_{4}$ are indicated with solid lines; concentrations of $\mathrm{C}_{2} \mathrm{H}_{2}, \mathrm{NO}_{x}$ and $\mathrm{CH}_{3} \mathrm{CCl}_{3}$ are indicated with dotted lines. A pollution plume is diagnosed at $5 \mathrm{~km}$. A biomass burning plume is diagnosed at $3 \mathrm{~km}$.

other regions of the world [Lelieveld et al., 1995], while higher values, up to 0.9 , have been reported for biomass burning plumes in the tropics which have aged several days in the free troposphere [Andreae et al., 1994, Mauzerall et al., 1995].
We thus estimate $B_{\mathrm{O} 3}=0.5 \times 10^{10}$ molecules $\mathrm{cm}^{-2} \mathrm{~s}^{-1}$ as the net contribution of biomass wildfire plumes to the regional ozone budget north of $45^{\circ} \mathrm{N}$ during ABLE 3B. Accounting only for the uncertainty in the enhancement ratio we obtain a range of $0-1.5 \times 10^{10}$ molecules $\mathrm{cm}^{-2} \mathrm{~s}^{-1}$. Ozone production within wildfire plumes thus appears to be a relatively negligible ozone source. As pointed out by Fan et al. [1994] and Singh et al. [1994], dispersion of PAN produced in fire plumes may provide a major source for the background $\mathrm{NO}_{x}$ observed in ABLE 3B. Biomass fires may thus have a major effect on regional ozone, not through ozone production in the fire plumes themselves, but rather through enhancement of background $\mathrm{NO}_{x}$ mixing ratios.

\section{Deposition}

We estimate the ozone deposition flux north of $45^{\circ} \mathrm{N}$ based on a map of surface types with $1^{\circ} \times 1^{\circ}$ resolution from Matthews [1985], and a mean summertime deposition velocity for each surface type as given by Jacob et al. [1992b]. The deposition velocity is referenced to $200 \mathrm{~m}$ altitude, where data from both ABLE 3A and ABLE 3B indicate a relatively homogeneous ozone concentration of about 25 ppbv [Browell et al., 1992, 1994]. Table 3 indicates the areal extent and ozone deposition velocity characteristic of each major surface type found north of $45^{\circ} \mathrm{N}$. Using an ozone concentration of $25 \mathrm{ppbv}$ at $200 \mathrm{~m}$, we estimate a regional ozone deposition flux of $9.4 \times 10^{10}$ molecules $\mathrm{cm}^{-2} \mathrm{~s}^{-1}$. We estimate uncertainty in this value at less than $50 \%$.

\section{Stratospheric Influx}

The final term in our ozone budget is the downward flux across the $6-\mathrm{km}$ altitude level representing the transport of ozone from the stratosphere and also the effect of net photochemical production in the upper troposphere. The upper troposphere is in general a net photochemical source of o7one [Liu et al., 1980], but this source cannot be quantified for high northern latitudes in summer because no observa-

Table 2. Concentratıon Enhancements $(\Delta)$ in Aged Biomass Wildtìre Plumes

\begin{tabular}{cccccccc}
\hline Mission & $\begin{array}{c}\text { Plume } \\
\text { Altitude, } \\
\mathrm{km}\end{array}$ & $\begin{array}{c}\Delta \mathrm{O}_{3}, \\
\mathrm{ppbv}\end{array}$ & $\begin{array}{c}\Delta \mathrm{CO}, \\
\mathrm{ppbv}\end{array}$ & $\begin{array}{c}\Delta \mathrm{NO}_{1}, \\
\mathrm{pptv}\end{array}$ & $\begin{array}{c}\Delta \mathrm{NO}_{\mathbf{r}} \\
\mathrm{pplv}\end{array}$ & $\Delta \mathrm{NO}_{1} / \Delta \mathrm{NO}_{1}$, & $\Delta \mathrm{O}_{3} / \Delta \mathrm{CO}$ \\
\hline 4 & 1.9 & $\mathrm{U}$ & 120 & 110 & 1200 & 0092 & $\mathrm{U}$ \\
6 & 2.8 & 12 & 65 & 250 & 1500 & $0) 17$ & 0185 \\
8 & 3.6 & $\mathrm{U}$ & 120 & $\mathrm{U}$ & 300 & $\mathrm{U}$ & $\mathrm{U}$ \\
9 & 3.0 & $\mathrm{U}$ & 70 & 20 & 650 & 0.031 & $\mathrm{U}$ \\
11 & 3.8 & $\mathrm{U}$ & 85 & $\mathrm{U}$ & 1200 & $\mathrm{U}$ & $\mathrm{U}$ \\
11 & 4.7 & 6 & 260 & 20 & 5000 & 0.004 & 0.023 \\
13 & 2.7 & $\mathrm{U}$ & 20 & 40 & 270 & 015 & $\mathrm{U}$ \\
13 & 4.4 & 19 & 60 & 20 & 470 & 0.15 & 0.317 \\
19 & 4.7 & 21 & 32 & $\mathrm{U}$ & 200 & 0 & 0.66 \\
& & & & & & & $0.1 \pm 02$ \\
& & & & & & & $($ meann) \\
\hline
\end{tabular}

U, undetectable. For averaging, considered equal to zero. 
Table 3. Areal Extent and Ozone Deposition Velocities for Surface Types North of $45^{\circ} \mathrm{N}$ in Summer

\begin{tabular}{lcc}
\hline Surface Type & \% Total Area ${ }^{\mathrm{a}}$ & $\begin{array}{c}\text { Deposition } \\
\text { Velocity, } \\
\mathrm{cm} \mathrm{s}^{-1}\end{array}$ \\
\hline Tundra & 9.6 & 0.20 \\
Deciduous Forest & 12.1 & 0.26 \\
Evergreen Forest & 14.1 & 0.23 \\
Shrub & 2.5 & 0.31 \\
Grassland & 6.4 & 0.42 \\
Cultivated & 5.5 & 0.43 \\
Ocean & 45.6 & 0.025 \\
Ice & 4.2 & 0.025 \\
\hline a Fraction of the total area north of $45^{\circ} \mathrm{N}$ contributed \\
$\quad$ by each land type. From Matthews [1985]. \\
b Jacob et al. [1992b]; referenced to 200-m altitude.
\end{tabular}

tions of $\mathrm{NO}_{1}$ are available. Literature estimates are, howev$\mathrm{er}$, available for the cross tropopause flux of ozone. Holton [1990] calculates a mass flux of air north of $23^{\circ} \mathrm{N}$ downwards across the 100 mbar surface of $19.8 \times 10^{8} \mathrm{~kg} \mathrm{~s}^{-1}$ in summer. Multiplying this value by the mean 100 mbar ozone mixing ratio at the Goose Bay and Churchill sondes stations in July and August of $1990(825 \pm 175 \mathrm{ppbv})$ [Environment Canada, 1990] yields a cross-tropopause ozone flux north of $23^{\circ} \mathrm{N}$ of $2.2 \times 10^{10}$ molecules $\mathrm{cm}^{-2} \mathrm{~s}^{-1}$ If we assume that all the influx occurs north of $45^{\circ} \mathrm{N}$, we obtain 4.6 $\times 10^{10}$ molecules $\mathrm{cm}^{-2} \mathrm{~s}^{-1}$. Levy et al. [1985] calculate a mean annual cross-tropopause flux of approximately $5 \times$ $10^{10}$ molecules $\mathrm{cm}^{-2} \mathrm{~s}^{-1}$ ozone in the northern hemisphere. At upper latitudes the exchange should be larger than average, while in summer it should be smaller than average [Holton, 1990]. A recent estimate of the influx of stratospheric ozone to the troposphere north of $60^{\circ} \mathrm{N}$ in summer, based on a meteorological analysis of ABLE 3A expedition data, obtains a value of $12 \times 10^{10}$ molecules $\mathrm{cm}^{-2} \mathrm{~s}^{-1}$ [Smarsh, 1994]. Thus from the literature we estimate ozone influx from the stratosphere north of $45^{\circ} \mathrm{N}$ during ABLE 3B to be in the range $2-12 \times 10^{10}$ molecules $\mathrm{cm}^{-2} \mathrm{~s}^{-1}$. In comparison, a derivation of the ozone flux at $6 \mathrm{~km}$ as the residual of our best estimates for the other terms in the ozone budget yields a value of $8.9 \times 10^{10}$ molecules $\mathrm{cm}^{-2} \mathrm{~s}^{-1}$. Closure of our ozone budget is reasonably well achieved.

\section{Discussion}

Table 4 summarizes our regional ozone budget for the 0 $6 \mathrm{~km}$ column at remote high northern latitudes in summer. The mean $0-6 \mathrm{~km}$ column concentration of $\mathrm{O}_{3}$ is $7.3 \times 10^{17}$ molecules $\mathrm{cm}^{-2}$. Photochemical loss and deposition add up to an estimated total sink of $32.4 \times 10^{10}$ molecules $\mathrm{cm}^{-2} \mathrm{~s}^{-1}$. The resulting ozone lifetime in the $0-6 \mathrm{~km}$ column is 26 days. We see from Table 4 that dispersed in situ photochemical production is the largest source of ozone in the region $(62 \%)$. Influx from the stratosphere / upper troposphere is of secondary importance $(27 \%)$, transport of pollution ozone from midlatitudes makes a small contribution $(9 \%)$, and production of ozone within forest fire plumes is a relatively

Table 4. Ozone Budget for the 0-6 km Column at Remote High Northern Latitudes in Summer

\begin{tabular}{|c|c|c|c|}
\hline & \multicolumn{2}{|c|}{$\begin{array}{l}\text { Column Rate. } \\
10^{10} \text { molecules } \mathrm{cm}^{-2} \mathrm{~s}^{-1}\end{array}$} & \multirow{2}{*}{$\begin{array}{c}\text { Fractional } \\
\text { Contribution } \\
\text { to Budget. } \\
\%\end{array}$} \\
\hline & Average & Range & \\
\hline \multicolumn{4}{|l|}{ Sources } \\
\hline Dispersed in situ photochemical production & 20 & $15-25$ & 62 \\
\hline $\begin{array}{l}\text { Net influx at 6-km altitude from upper tropo- } \\
\text { sphere / stratosphete }\end{array}$ & 8.9 & $2-12$ & 27 \\
\hline $\begin{array}{l}\text { Net influx of pollution ozone from mid lati- } \\
\text { tudes }\end{array}$ & 3 & $1-5$ & 9 \\
\hline Net ozone production in wildfire plumes & 0.5 & $0-1.5$ & 2 \\
\hline Total & 32.4 & $18-43.5$ & 100 \\
\hline \multicolumn{4}{|l|}{ Sinks } \\
\hline Dispersed in situ photochemical loss & 23 & & 70 \\
\hline Deposition & 9.4 & & 30 \\
\hline Total & 32.4 & & 100 \\
\hline
\end{tabular}


negligible term in the budget (2\%). Our conclusion that in situ photochemical production is the dominant ozone source for the region is a direct result of having separated ozone photochemical production from loss.

Earlier analyses of the Arctic and Subarctic during ABLE $3 \mathrm{~A}$ concluded that the stratosphere provided the primary source of ozone to the high latitude $\left(>60^{\circ} \mathrm{N}\right)$ troposphere in summer [Browell et al., 1992; Gregory et al., 1992]. Jacob et al. [1992a] calculated net ozone production $(P-L)_{\mathrm{O} 3}$ using the ABLE $3 \mathrm{~A}$ data set and found that although regional $\mathrm{NO}_{\text {, }}$ concentrations suppressed net photochemical loss and doubled ozone lifetimes compared with a $\mathrm{NO}_{\mathrm{r}}$ free atmosphere, $(P-L)_{03}$ was negative and ozone concentrations in the region were regulated primarily by input from the stratosphere and losses from net photochemistry and deposition. As can be seen from Table 4, in situ photochemical production and loss nearly cancel. However, since photochemical loss operates equally on all ozone regardless of its origin, we conclude that in situ photochemical production is in fact the largest source of ozone in the region, and hence that ozone levels are critically dependent on regional background $\mathrm{NO}_{\lambda}$ mixing ratios [Fan et al., 1994].

Ozone concentrations at high northern latitudes, both in ABLE 3B (Figure 3) and elsewhere [Logan, 1985], show a trend of increasing mixing ratios with altitude which has often been interpreted as reflecting a stratospheric source but could also be explained by net production in the upper troposphere [Liu et al. 1980; Jacob et al. 1995]. To confirm that our regional budget, as summarized in Table 4, is consistent with the observed vertical profile of ozone, we conducted an illustrative 1-D photochemical model calculation for ozone in the $0-6 \mathrm{~km}$ column under ABLE 3B conditions. Photochemical production and loss of ozone are computed at six model grid points $(0.5,1.5,2.5,3.5,4.5,5.5 \mathrm{~km})$. The concentrations of $\mathrm{CO}$, long-lived hydrocarbons, acetone, and water vapor are specified as a function of altitude from the mean values observed in background air (Figure 3). Total $\mathrm{NO}_{\mathrm{x}}$ is specified as a function of altitude as the sum of the mean background $\mathrm{NO}$ and the corresponding mean value of $\mathrm{NO}_{2}$ computed from the steady state model. Vertical transport is parameterized with an eddy diffusion coefficient $K_{-}=$ $1 \times 10^{5} \mathrm{~cm}^{2} \mathrm{~s}^{-1}$ [Liu et al., 1984]. An upper boundary condition of 75 ppbv ozone at $6.5 \mathrm{~km}$ is adopted. An ozone deposition velocity of $0.15 \mathrm{~cm} \mathrm{~s}^{-1}$ is used (the regional average of values in Table 3). Photolysis rate constants are calculated for clear-sky conditions as described previously. The model is integrated to a diel steady state defined by the reproducibility of ozone concentrations over the 24-hour solar cycle. To examine the influence of isoprene emissions, we conducted two simulations, one without isoprene flux, the other with a diurnally varying isoprene flux characteristic of the Schefferville forest site (24-hour average emission of $6.1 \times$ $10^{10}$ molecules $\mathrm{cm}^{-2} \mathrm{~s}^{-1}$ ). The difference in ozone concentrations between these two simulations was 3 ppbv at $0.5 \mathrm{~km}$ and less above. Since only $25 \%$ of the region north of $45^{\circ} \mathrm{N}$ is forested [Mathews, 1985] and emits isoprene at a rate similar to Schefferville forest, we plot the isoprene free simulation in Figure 9.

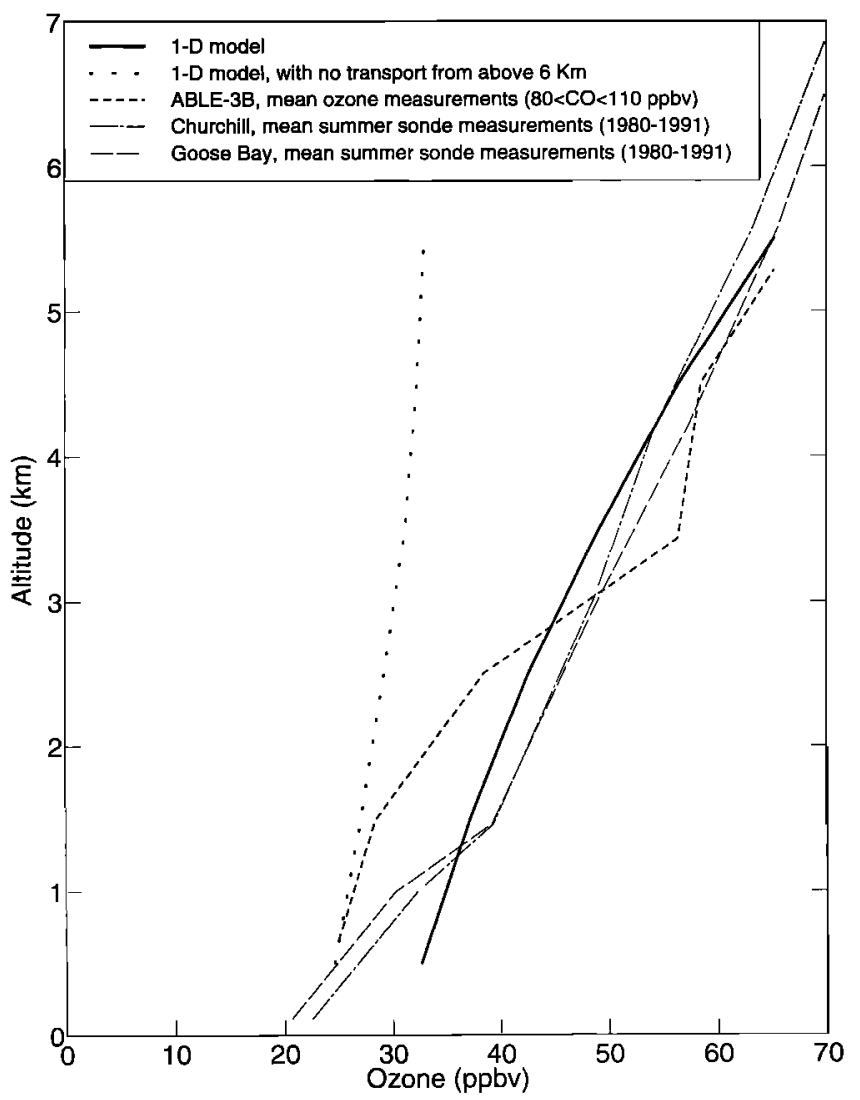

Figure 9. Vertical ozone profiles at high northern latitudes in summer including both measurements and 1-D model results.

Figure 9 shows that the 1-D model results are consistent with the observed ozone concentrations and vertical trends. Ozone production and loss in the $0-6 \mathrm{~km}$ column of the 1-D model are $25 \times 10^{10}$ and $27 \times 10^{10}$ molecules $\mathrm{cm}^{-2} \mathrm{~s}^{-1}$, respectively, and ozone loss via deposition is $13 \times 10^{10}$ molecules $\mathrm{cm}^{-2} \mathrm{~s}^{-1}$. These values are 20-40\% larger than those in our regional budget (Table 4). A downwards ozone flux at 6 $\mathrm{km}$ of $15 \times 10^{10}$ molecules $\mathrm{cm}^{-2} \mathrm{~s}^{-1}$ is needed for closure and would include contributions from pollution subsiding over the region as well as contributions from the stratosphere and from production in the upper troposphere.

Figure 9 also shows results from a 1-D sensitivity simulation with no transport of ozone across the top boundary at $6 \mathrm{~km}$, i.e., with ozone concentrations determined solely by in situ photochemistry in the $0-6 \mathrm{~km}$ column and by deposition. When compared to ABLE 3B observations the model profile indicates that in situ photochemistry within the 0-6 $\mathrm{km}$ column can account for nearly $90 \%$ of ozone in the boundary layer, while above $5 \mathrm{~km}$ it accounts for approximately $40 \%$. Transport from above 6-km appears necessary to reproduce the observed vertical gradient.

Our results are consistent with previous investigations of the origin of ozone at high northern latitudes based on correlations with the cosmogenic radioisotope ${ }^{7} \mathrm{Be}[$ Dibb et al., 1992, 1994]. These investigations documented significant stratospheric influence between 4 and $5 \mathrm{~km}$ altitude as indicated by elevated concentrations of ${ }^{7} \mathrm{Be}$ and $\mathrm{O}_{3}$ and a de- 
pressed dewpoint [Dibb et al., 1992]. However, they also showed that stratospheric inputs account for at most 10-15\% of $\mathrm{O}_{3}$ at the surface in springtime and less during the rest of the year [Dibb et al., 1994].

In the development of our ozone budget we have not been able to divide the natural from the anthropogenic contribution to the photochemical source term. Determination of the regional sources of $\mathrm{NO}_{x}$ is crucial in evaluating the influence of anthropogenic activities on the ozone budget at high northern latitudes; however, these sources are not well quantified. Talbot et al. [1994] argue that fire emissions appear to be the dominant source of reactive odd-nitrogen in the ABLE 3B region. Decomposition of PAN can account for most of the $\mathrm{NO}_{x}$ observed between the surface and $6 \mathrm{~km}$ in ABLE 3B, with much of the PAN believed to originate from biomass wildfires [Singh et al., 1994; Fan et al., 1994]. However some transport from anthropogenic mid-latitude sources is also evident in the ABLE 3B data [Talbot et al., 1994; Singh et al., 1994] with pollution appearing to be a major source for periodic elevation of $\mathrm{NO}_{x}$ and $\mathrm{NO}_{y}$ within the boundary layer at Schefferville [Bakwin et al., 1994]. To fully characterize the anthropogenic influence on the ozone budget in remote regions, a better understanding of the sources of PAN and other long-lived reactive nitrogen compounds to these regions is needed.

Figure 9 indicates that ozone mixing ratios measured during ABLE 3B in the boundary layer were approximately 10 ppbv below the 12 year (1980-1991) July-August mean concentrations derived from ozone sonde measurements at Goose Bay and Churchill. Mixing ratios in the free troposphere were in closer agreement. The disparity in the boundary layer might reflect the fact that burning which occurred in Canada in July and August of 1990 was only $60 \%$ of the average burning which typically occurred during these two months in the 1980s [Higgins and Ramsey, 1992]. However, analysis of the interannual variability of tropospheric ozone concentrations at Goose Bay over the period 1970-1993 shows no correlation between years of unusually large fire areas in Canada or Alaska and years of elevated ozone concentrations [Logan, 1994]. Long-range transport of fire products and/or anthropogenic pollution from Asia could possibly contribute significant $\mathrm{NO}_{\mathrm{x}}$ to the region via decomposition of PAN and other long-lived reactive nitrogen compounds. Such a contribution could obscure the influence of Canadian and Alaskan fires on ozone concentrations at these two sondes stations.

\section{Summary}

From data analysis and modeling using the measurements made during the ABLE $3 \mathrm{~B}$ expedition, we find that dispersed in situ photochemical production is the largest source of ozone in the $0-6 \mathrm{~km}$ column at remote high northern latitudes in summer $(62 \%)$. We find influx of stratospheric ozone to be of secondary importance $(27 \%)$, longrange transport of pollution ozone to make a small contribution $(9 \%)$, and photochemical production of ozone within biomass burning plumes to be a relatively negligible term in the budget (2\%). Illustrative 1-D model simulations indicate that within the boundary layer in situ photochemistry can account for nearly $90 \%$ of the ozone mixing ratio, while above $5 \mathrm{~km}$ it accounts for only about $40 \%$. However, although photochemical production of ozone within the 0-6 $\mathrm{km}$ column is larger than the other source terms combined, downward transport of ozone produced in the upper troposphere or stratosphere is necessary to explain the trend of increasing ozone mixing ratio with altitude.

The high northern latitudes are both a region of particularly strong transport from the stratosphere to troposphere [Danielsen, 1968; Shapiro et al., 1987] and an area where $\mathrm{NO}_{\mathrm{x}}$ concentrations are typical of the remote, and much lower than the urban, northern hemisphere troposphere [Carroll and Thompson, 1995]. Considering that in situ photochemical production is the dominant source of tropospheric ozone even in this region, we can extrapolate with some confidence to conclude that the ozone budget on the scale of the northern hemisphere troposphere is dominated by tropospheric photochemical production and loss. A better understanding of the $\mathrm{NO}_{x}$ budget is necessary to determine the fraction of photochemical ozone production that is due to anthropogenic rather than to natural $\mathrm{NO}_{x}$ emissions.

Acknowledgments. This paper has benefited from conversalions with Jennifer Logan and Steven Wofsy and from the comments of an anonymous reviewer. The work was supported by the National Science Foundation (NSF-ATM-9304217, NSF-ATM9320778), the Packard Foundation, the Tropospheric Chemıstry Program and the Global Tropospheric Experiment (GTE) of the National Aeronautics and Space Administration, the Department of Education (P200A00331), and by the National Aeronautics and Space Administration Graduate Student Fellowship in Global Change Research to Denise L. Mauzerall.

\section{References}

Anderson, B.E., G. L. Gregory, J. D. W. Barrick, J. E. Collins, G. W. Sachse, M. C. Shipham, and C. H. Hudgins, Summertime tropospheric ozone distributions over central and eastern Canada, J. Geophys. Res., 99, 1781-1792, 1994.

Andreae, M.O., B. E. Anderson, D. R. Blake, J. D. Bradshaw, J. E. Collins, G. L. Gregory, G. W. Sachse, and M. C. Shipham, Influence of plumes from biomass burning on atmospheric chemistry over the equatorial and tropical South Atlantic during CITE 3, J. Geophys. Res., 99, 12,793-12,808, 1994.

Atkinson, R.A., Gas-phase tropospheric chemistry of organic compounds: A review, Atmos. Environ., 24, 1-42, 1990.

Atkinson, R., D.L. Baulch, R.A. Cox Jr., R.F. Hampson Jr., J.A. Kerr, and J. Troe, Evaluated kinetic and photochemical data for atmospheric chemistry: Supplement IV, Atmos. Environ., 26A, $1187-1230,1992$.

Bakwin, P.S., et. al., Reactive nitrogen oxides and ozone above a taiga woodland, l8ïk, 1927-1936, 1994.

Barrie, L. A., Arctic air pollution: an overview of current knowledge, Atmos. Environ., 20(4), 643-663, 1986.

Browell, EV., C. F. Butler, S. A. Kooi, M. A. Fenn, R. C. Harriss, and G. L. Gregory, Large-scale variability of ozone and aerosols in the summertime Arctic and sub-Arctic troposphere, $J$. Geophys. Res., 97, 16,433-16,450, 1992.

Browell, E.V., M. A. Fenn, C. F. Butler, W. B. Grant, R. C. Harriss, and M. C. Shipham, Ozone and aerosol distributions in the sum- 
mertıme troposphere over Canada, J. Geophys. Res., 99, 1739 1756,1994

Carroll, M.A., and A.M. Thompson, $\mathrm{NO}_{\mathrm{x}}$ in the non-urban troposphere, in Advances in Physical Chemistry, edited by J. Barker, World Sci., River Edge, N.J., in press, 1995.

Chameides, W. L., and A. Tan, The two dimensional diagnostic model for tropospheric $\mathrm{OH}$ : An uncertainty analysis, $J$ Geophys. Res., 86, 5209-5223, 1981.

Chameıdes, W.L., D. D. Davis, G. L. Gregory, G. Sachse, and A. L. Torres, Ozone precursors and ozone photochemistry ovel eastern North Pacific durng the spring of 1984 based on the NASA GTE/CITE 1 arborne observations, J. Geophys. Res, 94, 9799-9808, 1989.

Chameides, W.L., et. al., Observed and model-calculated $\mathrm{NO}_{2} / \mathrm{NO}$ ratios during the NASA GTE/CITE 2 field study, $J$. Geophys. Res, 95, 10,235-10,247, 1990.

Chın, M., D. J. Jacob, J. W. Munger, D. D. Parnsh, and B. G. Doddridge, Relationship of ozone and carbon monoxide over North America and its implication for ozone production and transport. $J$ Geoplyys. Res., 99, 14,565-14,573, 1994.

Crawford, J., et al., A photostationary state analysis of the $\mathrm{NO}_{2} / \mathrm{NO}$ system based on airborne observations from the western and central North Pacific, J. Geophys. Res., in press, 1995.

Danielson, E.F., Stratospheric-tropospheric exchange based on radioactivity, ozone and potentral vorticity, $J$ Atmos. Sci., 25, 502-518, 1968.

DeMore, W.B., S. P. Sander, D. M. Golden, M. J. Molina, R. F. Hampson, C. E. Kolb, M. J. Kurylo, C. J. Howard, and A. R. Ravishankara. Chemical kinetics and photochemical data for use in stratospheric modeling, JPL publ., 92-20, 1992.

Dibb, J.E., R.W. Talbot, and G.L. Gregory, Beryllium 7 and lead 210 in the western hemısphere arctic atmosphere: Observations from three recent aircraft-based sampling programs. J. Geop/lys. Res., 97, 16,709-16,715, 1992.

Dibb. J. E.. L D. Meeker, R.C. Finkel, J.R. Southon, M W. Caffee, L.A. Barrie, Estimation of stratospheric input to the arctic troposphere: ${ }^{7} \mathrm{Be}$ and ${ }^{10} \mathrm{Be}$ in aerosols at Alert, Canada, J. Geophis. Res., 99, 12,855-12.864, 1994.

Environment Canada, Ozone data for the world, vol. 31, no 6. Atmospheric Environment Service, Halifax, N.S., 1990.

Fan, S.-M , D. J. Jacob, D. L. Mauzerall, J. D. Bradshaw, S. T. Sandholm, D. R. Blake, H. B. Singh, R. W. Talbot, G. L. Gregory, and G. W. Sachse, Photochemistry of reactive nitrogen in the subarctic troposphere in summer 1990: Observations and modeling, J. Geophys. Res., 99, 16,867-16,878, 1994.

Fishman, J., S. Solomon, and P.J. Crutzen, Observational and theoretical evidence in support of a significant in situ photochemical source of tropospheric ozone, Tellus, 3I, 432-446, 1979

Fitzjarrald, D.R., and K.E. Moore, Growing season boundary layer climate and surface exchanges in a subarctic lichen woodland. J. Geophys. Res., 99, 1899-1917, 1994.

Gregory, G. L., B.E. Anderson, L.S. Warren, and E. V. Browell, Tropospheric ozone and aerosol observations: The Alaskan Arctic, J. Geophys. Res., 97, 16,451-16,471, 1992.

Harriss, R.C., et al., The Arctic Boundary Layer Expedition (ABLE 3A): July-August 1988, J. Geophys. Res., 99, 16383 16394, 1992.

Harriss, R.C., S. C. Wofsy, J. M. Hoell Jr., R. J. Bendura, J. W. Drewry, R. J. McNeal, D. Pierce, V. Rabine, and R. L. Snell, The Arctic Boundary Layer Expedition (ABLE 3B): July-August 1990, J. Geophy's. Res., 99, 1635 -1645, 1994a.

Harriss, R.C., et al., Carbon monoxide and methane over Canada: July-August 1990, J. Geophys. Res., 99, 1659 -1670. 1994b.

Higgins, D.G. and G. S. Ramsey, Canadian Forest Fire Statistics: 1988-1990, Petawawa Natl. Forestry Inst., Forestry Canada 1992.
Holton, J. R., On the global exchange of mass between the stratosphere and troposphere, J. Atmos. Sci., 47, 392-395, 1990.

Intergovernmental Panel on Climate Change. Climate Change The IPCC Scientific Assessment, Cambridge Univ. Press, New York, 1990.

Jacob, D.J., et al., Summertime photochemistry of the troposphere at high northern latitudes, J. Geophys. Res., 97, 16421-16431. 1992a.

Jacob, D. J., S.-M. Fan, S. C. Wofsy, P. A. Sprro, P. S. Bakwin, J. A. Ritter, E. V. Browell, D. R. Bagwell, and C. H. Hudgins, Deposition of ozone to tundra, J. Geophys. Res., 97, 16,473$16,479,1992 \mathrm{~b}$.

Jacob, D.J., et al., Simulation of summertime ozone over North America, J. Geophys. Res., 98, 14,797-14,816, 1993.

Lacis, A.A., D. J. Wuebbles, and J. A. Logan, Radiative forcing of climate by changes in the vertical distribution of ozone, J. Geophys. Res., 95, 9971-9981, 1990.

Levy, H. II, J. D. Mahlman, and W. J. Moxim, Tropospheric ozone: the role of transport, J. Geophys. Res., 90, 3753-3772, 1985.

Lelieveld, J., P. J. Crutzen, D. J. Jacob, A. M. Thompson, Modeling biomass burning influences on tropospheric ozone, in The Southern Africa Fire-Atmosphere Research Initiative (SAFARI). The Ecological and Atmospheric Chemical Importance of Savannah Fires in the Southern Africa and Atlantic regions, edited by M.O. Andreae, J.G. Goldammer, J. Lindesay, and B. van Wilgen, University of the Witwaterrand Press, Johannesburg, in press, 1995.

Liu, S.C., D. Kley, M. McFarland, J. D. Mahlman, H. Levy II, On the origin of tropospheric ozone, J. Geophys. Res., 85, 75467552,1980

Liu, S.C., J.R. McAfee, R.J. Cicerone, Radon-222 and tropospherIC vertical transport, J. Geophys. Res., 89, 7291-7297, 1984.

Liu, S. C., M. Trainer, F.C. Fehsenfeld, D.D. Parrish, E.J. Williams, D.W. Fahey, G. Hubler, and P.C. Murphy, Ozone production in the rural troposphere and the implications for regional and global ozone distributions, J. Geophys. Res., 92, 41914207, 1987

Liu, S. C., et al., A study of the photochemistry and ozone budget durıng the Mauna Loa observatory photochemistry experıment, J. Geophys. Res., 97, 10,463-10,471, 1992.

Logan, J.A., M. J. Prather, S. C. Wofsy, and M. B. McElroy, Tropospheric chemistry: A global perspective, J. Geophys. Res., 86, 7210-7254, 1981 .

Logan, J. A., Tropospheric ozone: Seasonal behavior, trends, and anthropogenic influence, J. Geophys. Res., 90, 10,463-10,482, 1985.

Logan, J.A., Trends in the vertical distribution of ozone: An analysis of ozonesonde data, J. Geophys. Res., 99, 25,553-25,585, 1994

Matthews, E., Atlas of archived vegetation, land-use and seasonal albedo data sets, NASA, Technical Memorandum 86199, Feb. 1985.

Mauzerall, D. L., J.A. Logan, D.J. Jacob, B.E. Anderson, A.S. Bachmeier, G.W. Sachse, D.R. Blake, J.D. Bradshaw, H. Fuelberg. and B.G. Heikes, Relationships between biomass burning emissions and photochemical tracers over source regions and the tropical south Atlantic - analysis of TRACE A expedition measurements, September-October 1992, paper presented at Chapman Conference on Biomass Burning and Global Change, AGU, Williamsburg, Va., 1995.

Sandholm, et al., Summertime partitioning and budget of $\mathrm{NO}_{\text {, }}$ compounds in the troposphere over Alaska and Canada: ABLE 3B, J. Geophys. Res., 99, 1837-1861, 1994.

Shapiro, M.A., Turbulent mixing within tropopause folds as a mechanism for the exchange of chemical constituents between the stratosphere and troposphere, J. Atm. Sci., 37, 994-1004, 1980. 
Shapiro, M.A., T. Hampel, and A.J. Krueger, The arctic tropopause fold, Month. Weather Rev., 115, 444-454, 1987.

Shipham, M. C., A. S. Bachmeier, D. R. Cahoon Jr., G. L. Gregory, B. E. Anderson, and E. V. Browell, A meteorological interpretation of the Arctic Boundary Layer Experiment, ABLE 3B, flight series, J. Geophys. Res., 99, 1645-1657, 1994.

Singh, H.B., et al., Summertime distribution of PAN and other reactive nitrogen species in the northern high-latitude atmosphere of eastern Canada, J. Geophys. Res., 99, 1821-1836, 1994.

Smarsh, D. A., Meteorological investigation of ozone anomalies during the Arctic Boundary Layer Experiment (ABLE 3A), Doctoral dissertation, Ga. Inst. of Tech., Atlanta, 1994.

Staehelin, J., J. Thudium, R. Buehler, A. Volz-Thomas, and W. Graber, Trends in surface ozone concentrations at Arosa (Switzerland), Atmos. Environ., 28(1), 75-88, 1994.

Stocks, B. J., The extent and impact of forest fires in northern crrcumpolar countries, Global Biomass Burning, edited by Joel S. Levine, MIT Press, Cambridge, MA, 1991.

Talbot, R. W., et al., Summertime partitioning and budget of $\mathrm{NO}_{y}$. compounds in the troposphere over Alaska and Canada: ABLE 3B, J. Geophys. Res., 99, 1863-1886, 1994.

Trainer, M., et al., Correlation of ozone with $\mathrm{NO}_{1}$ in photochemically aged air, J. Geophys. Res., 98, 2917-2925, 1993.

Tuazon, E.C., and R. Atkinson, A product study of the gas-phase reaction of methyl vinyl ketone with the $\mathrm{OH}$ radical in the presence of $\mathrm{NO}_{1}$, Int. J. Chem. Kinet., 2I, 1141-1152, 1989.

Tuazon, E.C. and R. Atkinson, A product study of the gas-phase re- action of methacrolein with the $\mathrm{OH}$ radical in the presence of $\mathrm{NO}_{x}$, Int. J. Chem. Kinet., 22, 591-602, 1990a.

Tuazon, E.C. \& R. Atkinson, A product study of the gas-phase reaction of isoprene with the $\mathrm{OH}$ radical in the presence of $\mathrm{NO}_{\mathrm{x}}$, Int. J. Chem. Kinet., 22, 1221-1236, 1990 b.

Ward, D. E. and C. C. Hardy, Smoke emissions from wildland fires, Environ. Int., 17, 117-134, 1991.

Wofsy, S.C., S.-M. Fan, D. R. Blake, J. D. Bradshaw, S. T. Sandholm, H. B. Singh, G. W. Sachse, and R. C. Harriss, Factors influencing atmospheric composition over Subarctic North America during summer, J. Geophys. Res., 94, 1887-1897, 1994.

J. D. Bradshaw, School of Earth and Atmospheric Science, Georgia Institute of Technology, Atlanta, GA 30332.

D. R. Blake, Department of Chemistry, University of California at Irvine, Irvine, CA 92717.

S. -M. Fan, D.J. Jacob, and D. L. Mauzerall, Department of Earth and Planetary Sciences and Division of Applied Science, Harvard University, Cambridge, MA 02138 (email: dlm@io.harvard.edu).

G. L. Gregory and G. W. Sachse, NASA Langley Research Center, Hampton, VA 22331.

(Received October 25, 1994; revised October 3, 1995; accepted October 4, 1995.) 